\title{
Redefining and Integrating Jewish Writers into the Study of Historical Avant-Garde(s)
}

I will address the central question of this volume - how to integrate modern Jewish literatures into all areas of literary studies - by referring to the participation of Jewish writers in the Romanian and French avant-garde movements Dada and Surrealism in the first half of the twentieth century. After a short overview on the state of this research, I will offer a case study concerning Jewish writers of Romanian origins who emigrated to France, and more particularly Ilarie Voronca (1903-1946).

\section{State of research on the Jewish dimensions of the historical avant-garde movements}

In a recent study entitled Jewish Aspects in Avant-Garde. Between Rebellion and Revelation, the editors Mark Gelber and Sami Sjöberg conclude that, for all the important research from the last few decades, "no serious attempt has been made to understand the Jewish dimension of the avant-garde", the phenomenon as such remaining "largely uncharted". (Gelber and Sjöberg 2017, 1). Seeking a rather comprehensive answer to the question "how Jewish studies and avantgarde studies may benefit reciprocally from each other as interdisciplinary fields that complement each other's methodological repertoire" (Gelber and Sjöberg 2017, 12), both editors emphasize the necessity of a comparative approach which goes beyond micro-history, noting that "a method to clarify how one can approach both the avant-garde and Jewishness together on a more general level is still lacking”. (Gelber and Sjöberg 2017, 12) ${ }^{1}$

As Steven E. Aschheim acknowledges, most of the attempts that have been made to explain the prominent Jewish participation in the avant-garde(s) are

1 However, the complex and sometimes contradictory relationships between Jews and the avant-garde have generated important research in recent decades. Thus, in the above mentioned volume, Steven E. Aschheim identifies five major topics of study in this field: the role of writers and artists with a Jewish background within the various avant-garde movements, the role of Jewish cultures in the avant-garde(s), explicitly "Jewish" avant-garde projects, specific avant-garde attitudes to Jews, as well as anti-Semitic representations of Jews, particularly related to their participation in the avant-garde movements. (Aschheim 2017, 253)

Ә OpenAccess. () 2020 Iulia Dondorici, published by De Gruyter. (cc) BY-NC-ND This work is licensed under the Creative Commons Attribution-NonCommercial-NoDerivatives 4.0 License. 
"rather problematic". (Aschheim 2017, 253) The most frequent approach tend to see the anti-nationalism of the avant-garde as "particularly inviting" for Jewish artists and writers. (Gelber and Sjöberg 2017, 3) While this argument might be pertinent up to a point, Aschheim rightly points out that "the Jewish relationship to both 'official' and avant-garde culture and politics was generally tied to the complex dynamics, the possibilities and limitations of integration and assimilation”. (Aschheim 2017, 258)

This last point seems particularly pertinent with respect to the Romanian and Francophone avant-garde movements. Given the Jewish belonging of an overwhelming majority of writers and artists constituting these avant-garde groups, most scholars feel that an explication is needed for this phenomenon. Thus, the wide Jewish participation is considered to be the effect of the national(ist) ideology which, in the first half of the twentieth century, did indeed dominate all spheres of public life in Romania. ${ }^{2}$ In this context, Vasile Morar among others points to a more structural exclusion of Jewish writers from the definition of Romanian national literature and consequently from its literary canon and literary histories. ${ }^{3}$ He even goes so far as to consider the Jewish appeal for avant-garde literature and for modernity at large as an intrinsic feature of Jewish literatures in Romania. ${ }^{4}$

Nationalism and antisemitism in the Romanian society serve also to explain an overwhelming majority of Jewish-Romanian avant-garde writers chose to emigrate to Paris in the 1920s and 1930s. ${ }^{5}$ Beginning to write in French, so the argument continues, they successfully integrated themselves in the French avant-

2 S. Morar 2018, 178 and Stern 2017, 35-49.

3 This is particularly striking in the first two histories of Romanian literature that appeared in the first half of the twentieth century: Eugen Lovinescu: Istoria literaturii române contemporane (3rd vol., 1927) and George Călinescu: Istoria literaturii române de la origini până în prezent (1941). The canon that Lovinescu and Călinescu have established has been reproduced with little change in all subsequent literary histories, including the most recent one, published by the influential critic Nicolae Manolescu. S. Nicolae Manolescu: Istoria critică a literaturii române. Pitești 2008: Editura Paralela 45.

4 S. Morar 2006, 14-15. One of the unintended effects of this kind of argument is the complete marginalization of a large number of Jewish writers who did not (or not substantially) join the avant-gardes, like Mihail Sebastian, Isac Peltz or Sergiu Dan, just to mention a few.

5 In fact, we are often confronted with a non-linear migratory movement, as many avant-garde participants used to go back and forth between Bucharest and Paris in the 1920s and the 1930s. Moreover, during World War Two, they had to leave Paris either to find a refuge in the Southern of France (Ilarie Voronca, Claude Sernet, Benjamin Fondane, Tristan Tzara) or to leave Europe for North and South America. Others, like Céline Arnauld, had an errant, nomadic life in their childhood and youth and settled down in Paris, only to be obliged to flee in the face of the Shoah. 
garde movements, so far as to act as leaders of those movements: Tristan Tzara for the Dada movement and Isidore Isou for the lettrisme stand as paradigmatic examples of this phenomenon. Morar considers that the emigré Jewish writers from Romania have received in France - "the quintessentially cosmopolitan home of avant-gardism" - "wide recognition as major figures of modern poetry and art” (Morar 2018, 181). Sjöberg goes even further, stating that "on account of their linguistic abilities and aesthetic sensibility, Romanian Jewish writers were not as a rule to be found on the margins of such French avant-gardes as Dada, Surrealism or Lettrism" but, quite the contrary, "these figures were at the very core of the French avant-garde canon from the late 1910s to the early 1950s." (Sjöberg 2019)

If these arguments doubtless contain a grain of truth, they are nonetheless problematic in their presuppositions. Thus, Jewish participation is considered to be the result of the somehow 'evident' anti-national(ist) character of the avantgardes, though it would be more correct to acknowledge that it was on the account of the wide Jewish participation in the Bucharest avant-gardes that these movements movements acquired their strong anti-national(ist) character. Moreover, the implicit oppositions of transnationalism versus nationalism, and of (nationalist) Romania and (cosmopolitan) France are false. Indeed, transnationalism / internationalism and nationalism have coexisted in a majority of European avant-garde movements and groups, including those in Paris. ${ }^{6}$ Instead, it would be more accurate to affirm that the undeniably wide Jewish participation in the Romanian and Francophone avant-garde during the first half of the twentieth century happened in spite of avant-garde nationalism and even antisemitism, and adapted to it in different ways in Bucharest and Paris.

But, what is perhaps even more urgent to question here is the very need to account for the wide Jewish participation in the Bucharest-based avant-garde movements. This need presumes the often unconscious, but widespread idea that only "Romanian" (basically in the sense of ethnic belonging) writers are supposed to be the main (if not the single) agents of literary activities developing within the borders of a national territory.

I will finish this part of my article by pointing to a more nuanced argument in the context of Jewishness and avant-gardes coming from the sociology of literature, and more particularly from the theory of literary field by the French so-

6 As far as phenomena of antisemitism and nationalism are concerned, one should avoid the risk of a too clearcut opposition between Romania and France, as the French literary field as well, including the avant-gardes, was marked by antisemitic and national(ist) attitudes. As Thomas Hunkeler recently showed, a wide range of European avant-garde, including the Paris-based movements, were clearly marked by nationalist tendencies and attitudes. (Hunkeler 2018) 
ciologist Pierre Bourdieu. Thus, Bourdieu states that in nineteenth-century France, in the forefront of the literary field there are "bourgeois dévoyés ou déclassés qui possèdent toutes les propriétés des dominants moins une, parents pauvres des grandes dynasties bourgeoises, aristocrates ruinés ou en déclin, étrangers ou membres de minorités stigmatisées comme les juifs". (Bourdieu 1992, 88) The sociological research of Anna Boschetti and Norbert Bandier confirm a similar composition of the literary avant-garde at the beginning of the twentieth century. ${ }^{7}$ Thus, Anna Boschetti notes that in the Paris-based avantgarde groups there is "un grand nombre d'étrangers: Apollinaire lui-même, Cendrars, Beaudin, Guilbeaux, les futuristes. Apollinaire, Cendrars, Marinetti, Salomon et Carco ont mené, dans leur enfance ou dans leur jeunesse, une vie errante et cosmopolite. Max Jacob est juif.” (Boschetti 2001, 35) In this respect, Jewishness is no exclusive or singular attribute of the avant-garde agents, but migration and foreignness at large are significant factors as well.

\section{Jewish writers, Romanian and French literary histories}

Ilarie Voronca can be considered one of the most original and prolific avantgarde writers in either Romanian or French. In Bucharest he was co-founder of two of the most significant avant-garde magazines, $75 \mathrm{HP}$ (1924) and Integral (1925-1928). Later on, he was a steady contributor to the main Surrealist revue ипи (1928-1932). After making his debut in 1922 in the most prestigious literary circle of the time, Sburătorul, with its eponymous magazine - both led by the influential literary critic and historian Eugen Lovinescu - Voronca published an impressive number of volumes not only with different small avantgarde publishers in Bucharest, but also with more prestigious publishers such as "Vremea" and "Cultura Națională". Voronca thus had a well-established reputation in the Romanian literary field at the moment of his emigration to France. After moving back and forth between Bucharest and Paris from 1925 to 1932, Voronca and his wife, Colomba Voronca, finally settled down in Paris in 1933.

A similar development involves two other Jewish avant-garde poets, Benjamin Fundoianu/Benjamin Fondane (1898-1944) and Mihail Cosma/Claude Ser-

7 S. Boschetti 2001, 33-35; Bandier 1999, 271-336. As for the Surrealist group around Breton, its core members were French, most of them even Parisian. 
net (1902-1968). ${ }^{8}$ Both were members of the group "Integral" and steady contributors to its review. Although they emigrated to France much earlier in their careers, they created a bilingual literary work and participated equally in avant-garde endeavors in Bucharest and Paris. All three worked as literary translators (from Romanian to French and vice versa) and acted as cultural mediators. As Sernet left Bucharest for Padova already as an undergraduate student and moved from there to Paris in 1925, his literary work in Romanian is much less significant than his writing in French. Fondane left for Paris as a young poet, in 1923, after an extensive engagement with avant-garde theater in Bucharest he had co-founded the avant-garde theater group "Insula" with the stage director Armand Pascal. His first book of literary essays, Imagini și cărți din Franța (1921), published with the prestigious house "Cultura Națională”, generated a heated debate and made his author known in literary circles overnight. From Paris, Fondane contributed to influential Romanian avant-garde reviews like Contimporanul (1923-1933), Integral and unu. ${ }^{9}$

These itineraries clearly show that all three poets - Ilarie Voronca, Benjamin Fundoianu/Fondane und Mihail Cosma/Claude Sernet - were in different degrees deeply integrated in the Romanian literary field of their time. At the socalled "pôle restraint" of this field, where the literary avant-gardes must be situated according to Bourdieu, these poets definitely were main actors. Thus, they co-founded the most significant avant-garde groups and reviews in Bucharest in the 1920s and 1930s: 75HP, Punct, Integral and contributed to other main reviews: Contimporanul and unu. Emigration to Paris did not interrupt their literary and artistic engagement in Bucharest. In the Romanian capital, they seem to have had good publication opportunities, at specific avant-garde publishers as well as at big, well-established publishing houses. They were part of a large network of artists and writers, and disposed of valuable contacts and connections in the literary and artistic field - in a word, of high social and cultural capital such as they could founf groups and reviews that remained active for many years.

Thus, it seems that the widely spread antisemitic and nationalist attitudes in the Romanian artistic and literary world, instead of inhibiting avant-garde activities in general and the engagement of Jewish writers in them in particular, acted as a kind of catalyst for them. These avant-gardes groups instead seem to have developed into an inclusive, protective space for aesthetic (and implicitly polit-

8 Both changed their pen names after emigration. At the beginning of their careers in Bucharest Fondane signed Benjamin Fundoianu and Sernet, Mihail Cosma.

9 In 1930, “Cultura națională” published a volume with Fondane’s Romanian poems from 1917 to 1923 under the title Priveliști. Poeme 1917-1923. 
ical) activities, an experimental space for otherwise marginalized Jewish writers. In this context, reviews like Contimporanul and Integral openly denounced the antisemitic and nationalist attitudes in Romania and fought against them. If the response of the literary and artistic establishment was not enthusiastic, this is part of a general rejection and even aggressive attitude towards avantgarde movements throughout Europe. However, as far as individual writers are concerned, a wide positive reception was possible in Romania. This was the case for Ilarie Voronca at the end of the 1920s and the beginning of the 1930s, before and about the time of his emigration to Paris. ${ }^{10}$

This analysis leads us to the conclusion that, in addition to the widespread nationalism and antisemitism of Romanian society, some other possible reasons for the emigration of avant-garde Jewish writers from Romania to France in the 1920s and 1930s should be taken into consideration. ${ }^{11}$ One further reason might have been their legitimate desire to gain recognition in a country that was (and still is) perceived as the very center of an international and transnational literary and artistic avant-garde. The emigration option was clearly facilitated by the multilingualism of the writers as well as by a large network of relationships they had successfully established all over Europe and even beyond. Indeed, through the group Integral and the eponymous review, as well as the international exhibitions previously organized in Bucharest, Voronca, Fondane and Sernet were well aware of contemporary avant-gardes throughout Europe, being even able to offer a platform of expression to numerous fellow writers and artists. ${ }^{12}$

Voronca's publications shortly after his settlement in Paris as well as the collaborative work in which he was constantly engaged clearly support this statement. Thus, the poet had almost all his volumes illustrated by artists like Sonia and Robert Delaunay, Victor Brauner, Marc Chagall and Constantin Brâncuși. Voronca translated into French and published two of his last Romanian vol-

10 Thus, Voronca's last volumes in Romanian had numerous reviews, written by young as well as by established literary critics (Eugen Ionescu, Emil Gulian, Pompiliu Constantinescu, Perpessicius) in influential literary magazines like Romania literară, Vremea or Viața românească. 11 This is not to downplay the important role of antisemitic and nationalist attitudes in this context. However,Voronca's emigration to Paris clearly took place in the context of a deep existential crisis, probably reinforced by the fact that from 1932 the Romanian avant-garde scene was also in a transitory stage, with hardly any magazines and organized groups.

12 Among the international contributors to Integral there were Sonia und Robert Delaunay, Alice Halicka, Georges Ribemont-Dessaignes, Joseph Delteil, Max Jacob, Roger Vitrac, Tristan Tzara, Marcel Raval, Céline Arnauld, Paul Dermée, Pierre Reverdy, Michel Seuphor, to mention just a few. 
umes: Peter Schlemihl (1932) and Patmos (1933). ${ }^{13}$ In 1933, his volume Ulise - perhaps the volume which received most positive reception during his life as well as posthumously - was translated into French by the avant-garde poet Roger Vailland, one of the core members of the Surrealist group "Grand Jeu” and prefaced by Georges Ribemont-Dessaignes, well-known for his Dadaist and more generally avant-garde activities. ${ }^{14}$ After these translations, the volume Permis de séjour (1935) was Voronca's first volume written directly in French. While Ulysse dans la cité appeared with La Sagittaire - the Surrealist publisher in Paris par excellence - all the other three volumes mentioned were published either "en compte d'auteur" or in small magazine collections like "Les Cahiers du Journal des poètes", the latter based in Brussels. The same is true for all of Voronca's subsequent publications. ${ }^{15}$ Similarly, his literary works have only been re-published sporadically after his death in $1946 .^{16}$

As for Fondane and Sernet, their situation was not much different. Fondane was able to publish his first book only five years after emigrating, in the collection of the avant-garde magazine Documents internationaux de l'Esprit Nouveau (1927); his following two volumes of poetry appeared in the collection of the Brussels-based "Les Cahiers du Journal des Poètes". Three years after arriving in Paris, Sernet co-founded the group and the magazine Discontinuité (1928). The fact that Discontinuité had only one issue, and that afterwards Sernet needed nine further years to be able to publish his next volume, signify his poor social and cultural capital in Paris. ${ }^{17}$

If it is true that Voronca as well as Fondane and Sernet were able to integrate themselves in the French avant-garde field - basically because of their adopting French as the language of their further literary creation as well as their participation in a large artistic network in the Parisian field - they nonetheless participated exclusively in marginal groups. Thus, they were at all times excluded from the main avant-garde group, the Surrealist group around Breton, which from the beginning of the 1920s dominated the avant-garde field in Paris. Neither Voronca

13 Both appeared in French in 1934, the first as Poèmes parmi les hommes and the second under the same title.

14 Voronca himself co-translated this volume.

15 Sagittaire will publish one more book by Voronca, La beauté de ce monde, in 1940.

16 A new edition of La poésie commune appeared in 1979 (Paris: Plasma), Journal inédit suivi de Beauté de ce monde appeared in 2018 (Paris: Les Hommes sans Épaules éditions), Petit Manuel du parfait bonheur and Ulysse dans la cité were republished in 2019 (Paris: Cambourakis and Paris: Non Lieu respectively).

17 Commémorations (1937) and Un jour et une nuit (1938) were published by Tschad and Sagesse respectively, two small Paris-based publishers. 
nor Sernet or Fondane were part of it or established close relationships with any of its influential members. Whereas the group that was best anchored and most powerful in the Parisian literary field at the time was evidently close to nonFrench migrant writers, the three Jewish poets approached rather marginal Parisian and Belgian Francophone avant-garde groups and reviews like the Surrealist Le Phare de Neuilly (1933), the group Discontinuité (1928), most of whose members were non-French migrant writers and artists, the group Le Grand Jeu (19251928) or Le Journal des Poètes, a Francophone journal more generally committed to modernist aesthetics without committing itself to a specific avant-garde affiliation.

While scholars keep mentioning the success they enjoyed in France, the position of Voronca, Fondane and Sernet in the French literary field in the 1930s and 1940s as described here, as well as their hardly existent place in the French literary history until today, might well cast serious doubts on this statement. So, as far as their positions in the literary field are concerned, emigration hardly constituted an improvement - as can be seen with respect to the kind of publishing houses they are able to place their volumes, the magazines to which they contribute as well as their engagement in avant-garde groups.

In this respect, not even Tristan Tzara is a genuine exception. Thomas Hunkeler, in the above mentioned study on the nationalism of the European avantgarde, clearly shows Tzara's marginalization in the French literary field of the 1920s and 1930s. Largely concerted by "Breton et ses amis", this marginalization even seems to have been part of Breton's and Aragon's strategy of presenting Paris Dada as a genuinely French movement and thus gaining more acceptance for the avant-garde in general and for the emerging Surrealist movement in particular. (Hunkeler 2018, 231-237) If Tristan Tzara has indeed an important place in the memory of the French avant-garde today, this is rather due to his later approach to the Surrealist group around Breton as well as to the enormous cultural and social capital he had managed to acquire in the Zurich Dada. The huge Dada archive he possessed in Paris and the intense (auto)promotion work he was able to do worldwide after WW II was also decisive in this unique recuperation process, so that Tzara can now be largely perceived as the "chef de file" of the Dadaist movement in Paris.

The fact that Tzara wrote almost his entire literary work in French also facilitated his perception as a Francophone, if not French, poet. This is also true for Sernet and Fondane, so that they could be re-published and studied in the context of the French avant-garde, though as marginal actors. This is much less the case for Voronca, who wrote as much of his poetry in Romanian as in French, and is rather perceived as a bilingual writer, belonging to the Romanian and to the French literature as well. Given that literary history is still mostly written 
in a national framework, this double bind, linked to migration and multilingualism, proved rather a disadvantage. Thus, the research on Romanian avant-gardes retains mainly Voronca's activities in Bucharest and his literature in Romanian, while the little research in French on him focuses on his poetry in this language. As the translations are still missing, his entire literary work is available neither in Romanian nor in French. However, as far as the histories and more general research work on the Bucharest-based avant-gardes are concerned, Voronca and, to a lesser degree, Sernet and Fondane are perceived as main actors of these movements. Their central positions in the Romanian avant-garde histories are reinforced by their (real or alleged) success in Paris - their emigration into a more prestigious, "Western" literary field was and still is a source of literary and cultural capital in the context of a 'small', 'peripheral' literature such as the Romanian.

\section{Migrant perspectives on Paris in Voronca's avant-garde poetry}

Voronca's emigration to Paris meant a turning point in his life, and this significance was thoroughly documented in his poetry. As his enthusiastic engagement in such various avant-garde projects as 75HP, Punct, Integral and unu shows, Voronca was not the kind of poet committed to a single movement or to a unique aesthetic. On the contrary, he experimented with various avant-garde poetics and directions, including Dada, Constructivism, Surrealism, as well as Integralism. ${ }^{18}$ As was the case for Surrealist poets around André Breton, the city of Paris exerted a constant fascination on Voronca, who dealt with it in at least two of his major poems, Ulysse dans la cité (1933) and Permis de séjour (1935). The first was published in Romanian in 1928; the latter is Voronca's first poem written and published in French after establishing himself in Paris. As for his view on the French metropole, the two poems - separated by the experience of emigration - could not be more different, as I will show in a short comparative reading. ${ }^{19}$

18 For the development of Voronca's poetry and his avant-garde activities in Romania, s. Pop 2015.

19 Pop also states a radical difference between Voronca's poetry before and after 1931 and the subsequent emigration, but in order to claim that the latter does not any longer belongs to the avant-garde: "Ilarie Voronca as militant avant-garde poet existed only in the Romanian cultural context, during a period in his life when he was enthusiastically engaged with experiments in 'extreme' modernity, fighting against all 'conventions', whether stereotypes in poetic language or the conformism of the 'bourgeois' spirit” (Pop 2015, 15). 
As contemporary critics noticed, Ulysse dans la cité is a modern reworking of the ancient myth and a literary documentation of the poet's life as a traveller - a traveller between Bucharest and Paris and a wanderer through these both cities. Inspired by Apollinaire's Zone as well as by Reverdy's conception of the poetical image, Voronca's poem shows an enchanted wanderer, whose zigzag movement encompasses various spaces. He explores small provincial towns as well as the metropole, countryside and an urban space depicted with its large central boulevards as well as with its peripheral spaces. Paris becomes an explosion of colors and sounds. The urban space embeds all of nature and extends to the universe, whereas the different, often disparate elements engage in a sensual, erotic relationship.

This modern Ulysses accomplishes his journey by arriving in Paris, a city that he recognizes and that calls forth memories and images from other journeys and past stays here. These last lines of the poem depict Paris as the quintessence of the modern metropole: ${ }^{20}$

\author{
paris oraș ca o volută ca o amintire \\ cum îți cunosc mansardele barurile cinematografele [...] \\ piața concordiei ca un pântec se rotunjește se ridică \\ bulevardele sună panoplia cuvintelor în luceferi \\ desigur cerul sărută acoperișul bisericilor căzărmilor \\ și turnul eiffel își întinde gâtul \\ sângele acensoarelor circulă în marile hoteluri [...] \\ paris ulei sfânt pentru încheietura gândului \\ oscilează pe harta apusului ca un transatlantic \\ te stingi ca o mătase pe buzele toamnei (Voronca 2003, 40-41) \\ paris a city like a volute like a memory \\ how well do I know your attics bars cinemas [...] \\ place concorde round like a belly standing up \\ the boulevards jingle the panoply of words in the stars \\ of course the sky kisses the roofs of the churches of the barracks \\ the eiffel tower stretches its neck \\ the blood of the lifts circulates through the grand hotels [...] \\ paris holy oil for the accomplishment of thoughts \\ oscillates on the sunset's map like a transatlantic ship \\ you set like silk on autumn's lips ${ }^{21}$
}

20 Ion Pop points out the "overflow of images" in Voronca's poem. He writes: “The topos of the magical city with its illuminated billboards and colorful streets and crowds returns again and again in Voronca's verses, which suggest a particularly urban type of dynamism, rich with bold images.” (Pop 2015, 10)

21 Working translation mine. 
Permis de séjour signifies a radical change of perspective on Paris, with the theme of migration as the focus of the poem. The metropole is now depicted in its nameless, poor, peripheral places. While in the previous volume the welcoming, embracing metropolitan space was populated by the poet's friends (sometimes mentioned with their real names) and by inhabitants participating in the urban daily life, solitude and fear now take hold of a disenchanted, cold space, that no longer resonates with the narrator's feelings and his experiences as a migrant:

Dans ce monde nouveau, j'avais peur, je marchais doucement.

Je ne savais pas comment il fallait me tenir, comment

Il fallait respirer? Et mes mains? Que devais-je en faire?

Ballantes, elles se heurtaient aux murs, aux réverbères,

De grand morceau de ciel empêchaient mes mouvements,

Il fallait tout recommencer. Tout réapprendre. [...] (Voronca 1935, 15)

And:

On pourrait très bien monsieur, vous engager,

Mais notre maison ne prend plus d'étrangers,

Ni de poètes... J'avais faim. Un brouillard montait vers la cité.

Loin ou près, les étoiles faisaient leur publicité. (Voronca 1935, 25-26)

The travelling and wandering poet from Ulysse dans la cité has now become the wandering Jew and the poems in Permis de séjour are conceived around the figure of the poet as a perpetual stranger, the stranger par excellence. A poet-narrator obsessed by the impossibility of making his words heard, dominated by the fear of disappearing without leaving any tracks of his passage. ${ }^{22}$

The urban space is divided into rich and poor quarters, and he, like the other étrangers clearly belong to the latter. The French word "étranger" (engl. "stranger", "foreigner") designates the status of the narrator in a double way: he is a foreigner, a migrant and a person who, as a poet, incorporates strangeness and remains strange to this city. The emigration is by no means the beginning of a new life, the streets of Paris rather recall death, as they resemble cemeteries. Thus, the narrator is continually in search of a refuge from the new world he has arrived in, while the rain is falling and the wind keeps blowing:

22 "Ici, comme partout ailleurs, ma voix est étrangère, / Partout je suis l'errant. Je ne serai nulle part / Celui qu'on attend. Il faut que je pense au départ” (Voronca 1935, 26) 
[...] Je n'avais moi-même nul abri. L'eau,

La même eau, tombait triste, noirâtre comme dans la ville

Lointaine et pauvre d'où je venais. Nulle île

Pour fuir cette pluie... Il faisait froid. (Voronca 1935, 16)

The new home is not much different from the old one that he left behind, and is actually no home at all. Both cities are thus infused by an imaginary third space, a kind of paradise or a social utopia - the island and the sea:

\author{
Nulle part un toit hospitalier, une mer bien heureuse \\ Caressant doucement les joues des rives lumineuses. [...] \\ Des gens très doux, très polis seraient descendus vers les plages, \\ Et moi parmi eux tous, emmêlant nos visages, \\ Planant entre les vitres claires, hautes des maisons, \\ Frères tous, nous tenant par la main, si lumineux, si bons. \\ Mais non, ici comme là-bas cette rivière morne, \\ Ces souffles citadins, ces tristesses sans bornes, \\ Cette ville de boue et de brume dont le nom \\ Qu'importe? fût-il Paris, Londres ou Capetown. \\ Ici comme ailleurs, ces maisons qui s'écroulent \\ Et ces ponts sous lesquels un jour laiteux s'écoule. (Voronca 1935, 24-25)
}

The social utopia depicted here as an imaginary space immersed into light, a welcoming space where people behave like "brothers", announces a new phase in Voronca's poetry, inaugurated by his next volume, La poésie commune. There, his preoccupation for the life of ordinary people leads to a radical reworking of his poetics, so that Voronca's subsequent avant-garde poetry is meant to be accessible to ordinary people and to liberate them. At the same time, it announces a future time of happiness and brotherhood. Through a series of bright images, this utopia is clearly opposed to the darkness and coldness of the real city. It is not the Paris at night full of fascination and wonders (le merveilleux) praised by the Surrealists and by Voronca's Ulysses, but a darkness signifying loneliness, sadness, fear and material misery. The metropole has lost not only all its magic, but also its identity, and it is not the desired arrival point anymore, but seems to be interchangeable with any other metropolis like London or Capetown. The last verse recalls the refrain of Apollinaire's poem Le Pont Mirabeau, but in a "milky" daylight, the landscape has lost all its beauty and melancholy.

The distance that separate Ulysses from the wandering Jew - both mythical figures that the poet embodies - is clearer than ever in the following verses:

Je ne vous imposerai pas des villes, des rues, Je ne tracerais pas la route d'autres migrations, Je ne fonderai nulle famille, nulle nation [...] (Voronca 1935, 33) 
And:

Je sais que cette argile n'est pas à moi. Non pas.

Mais elle n'est à personne. La trace de ce pas

N'est-elle pas plus libre que le pied qui l'a faite? (Voronca 1935, 41-42)

If, as David Pindar claims, the Surrealist movement is concerned with "resisting nationalistic and imperialist geographical imaginations" (Pindar 2009, 88), then Voronca's imagery of the modern metropole from the perspective of the stranger, or the migrant, errant poet is to be subsumed as an integral part of the Surrealist and more generally avant-garde imaginary and its thematic reservoir.

\section{Conclusions: Jewish writers as integral part of the transnational avant-garde(s)}

The 'problematic' state of research on Jewish writers in the Romanian and French avant-garde(s) reflects more general theoretical and methodological shortcomings of existing scholarship on the avant-garde movements. Firstly, as more and more scholars point out, the avant-garde movements continue to be studied within different national philologies and/or in a comparatist framework, thus being unable to account for their transnational, global character. It thus comes as no surprise that the question of Jews and/in the avant-garde(s) has hardly been explored in general or overview studies on the avant-gardes, nor can we find it in theoretical studies.

I will conclude by claiming that only a transnational and global framework for the study of the avant-gardes can account for the Jewish dimensions of these movements. Moreover, this transnational framework of (historical and theoretical) analysis of the avant-garde(s) must integrate the following two phenomena as its constitutive elements: migration as a global process, constitutive for the avant-garde phenomenon as well as the multi- and translingualism of the avant-garde(s).

As shown here, writers and artists with a Jewish historical experience stand for a specific form of diasporic and migrant belonging which is crucial for the emergence and the development of avant-garde movements. Avant-garde movements in Bucharest and in Paris are multilingual avant-garde(s). Whereas monolingualism is rather an exception, basically characteristic for those Paris based groups which had hardly migrants in their rows, in concepts of the avantgarde it is still regarded as the norm. The multilingualism of Jewish writers integrates itself into avant-garde aesthetics and practices, and a transnational frame- 
work would allow to account for a variety of forms of multilingualism more specific for Jewish writers in a wide range of local contexts.

\section{Bibliography}

Aschheim, Steven E. "The Avant-Garde and the Jews." Jewish Aspects in Avant-Garde. Between Rebellion and Revelation. Eds. Mark H. Gelber and Sami Sjöberg. Berlin: De Gruyter, 2017. 253-273.

Bandier, Pierre. Sociologie du surréalisme. Paris: La Dispute, 1999.

Boschetti, Anna. La poésie partout. Apollinaire, homme époque (1898-1918). Paris: Seuil, 2001.

Bourdieu, Pierre. Les règles de l'art. Genèse et structure du champ littéraire. Paris: Seuil, 1992.

Gelber, Mark H. and Sami Sjöberg. "Introduction.” Jewish Aspects in Avant-Garde. Between Rebellion and Revelation. Eds. Mark H. Gelber and Sami Sjöberg. Berlin: DeGruyter, 2017. 1-21.

Hunkeler, Thomas. Paris et le nationalisme des avant-gardes (1909-1924). Paris: Hermann, 2018.

Lascu, Mădălina (ed.). Epistolar avangardist. Bucharest: Tracus Arte, 2012.

Morar, Ovidiu. Scriitori evrei din România. Bucharest: Ideea Europeană, 2006.

Morar, Ovidiu. "Cosmopolites, Deracinated, étranjuifs: Romanian Jews in the International Avant- Garde." Romanian Literature as World Literature. Eds. Mircea Martin and Andrei Terian. New York: Bloomsbury Academic, 2018. 175-195

Pindar, David. "Surrealism. Surrealist Geographies." International Encyclopedia of Human Geography. Volume 11. Eds. Rob Kitchin and Nigel Thrift. Amsterdam: Elsevier, 2009. 87-94.

Pop, Ion. "Ilarie Voronca and the Romanian Literary Avant-Garde." Dada/Surrealism 20 (2015). https://doi.org/10.17077/0084-9537.1297 (26 November 2019). 1-16.

Sjöberg, Sami. “An Other Transnationalism. Romanian Jewish Emigrants in Francophone Avant-Garde Literature.” French Studies. 73.1 (2019): 33-49.

Stern, Radu. "Jews and the Avant-Garde: The Case of Romania." Jewish Aspects in Avant-Garde. Between Rebellion and Revelation. Eds. Mark H. Gelber and Sami Sjöberg. Berlin: De Gruyter, 2017. 35-51.

Voronca, Ilarie. Ulise. Brățara nopților. Cluj-Napoca: Dacia, 2003 [1928].

Voronca, Ilarie. Permis de séjour. Paris: Éditions R.- A. Corrêa, 1935. 